UDC 69.001.5+ 696.1

Author: KUDRYAVTSEV Pavel Gennadievich, Professor, D.Sc., Leading Researcher Polymate Israel Research Center (Israel), Academician of International Academy of Sciences for Ecology and Human Safety and Russian Academy of Natural Sciences, Author of 207 scientific works, including 4 monographs, has 34 inventions. He was awarded the M.V.Lomonosov medal, Commander of the Order «The Star of the Scientist» and was awarded the honorary title «Honored Worker of Science», awarded the medal of P.A. Stolypin, and honorable diamond sign of the Chamber of Commerce and Industry of the Russian Federation. Polymate Ltd. - Israel Research Center, POBox 73, Migdal HaEmek 10550, Israel, e-mail: pgkudr89@gmail.com;

Author: KUDRYAVTSEV Nikolai Pavlovich, Engineer-researcher Polymate - Israel Research Center (Israel), Author of 9 scientific works, has 4 patents; Diploma of Perm national research polytechnic university of Fuel and Natural Energy Carriers; Passed internship at the University Friedrich-Alexander Erlangen and Nurnberg (Germany): Physico-chemical basis of separation processes; POBox 73, Migdal HaEmek, Polymate Ltd. - Israel Research Center, 2320001, Израиль, e-mail: nikkudr@yahoo.com;

Author: FIGOVSKY Oleg Lvovich, Professor, Full Member of European Academy of Sciences, Foreign Member of REA and RAASN, Editor-in-Chief of Journals SITA (Israel), OCJ and ICMS (USA), Director for Research and Development Polymate - Israel Research Center (Israel) and Nanotech Industries Inc., (USA); Chairman of the UNESCO chair «Green Chemistry»; President of Israel Association of Inventors; Laureate of the Golden Angel Prize, Commander of the Order «Engineering glory» (Russia) and «Leading Intellectuals of the World» (USA). Polymate Ltd. - Israel Research Center, POBox 73, Migdal HaEmek 10550, e-mail: figovsky@gmail.com

\title{
PURIFICATION OF INDUSTRIAL AND WASTE WATER USING MATRIX- ISOLATED NANOCOMPOSITE FLOCCULANT-COAGULANTS
}

\section{EXTENDED Abstract:}

The paper presents the results of studies on the industrial purification of oil-containing wastewater with the use of new nanocomposite flocculants-coagulants ASFC and ISFC. They were tested using the methods of wastewater treatment industries, as well as rain water containing oil. Specific examples of water purification were examined, using new aluminum-silicon and iron-silicon flocculants-coagulants. The authors have developed and patented the technology of obtaining flocculants-coagulants of this type in solid form. To produce such composite materials, the method of matrix isolation of active components was used. An efficiency of coagulants-flocculant ASFC and ISFC used in real industrial 
wastewater has been evaluated. Comparison was made for new composite materials with known analogues.

Key words: reagent water treatment, natural waters, wastewater, flocculants-coagulants, matrix insulation, nanocomposites, ASFC, ISFC

DOI: dx.doi.org/10.15828/2075-8545-2017-9-3-44-61

Machine-ReAdable information on CC-LiCEnses (HTML-Code) in METAdata of THE PAPER

$<$ a rel="license" href="http://creativecommons.org/licenses/by/4.0/" $><$ img alt="Creative Commons License" style="borderwidth:0" src="https://i.creativecommons.org/l/by/4.0/88x31.png" / $></ \mathrm{a}><$ br $/><$ span xmlns:dct="http://purl. $\mathrm{org} / \mathrm{dc} /$ terms $/$ " property="dct:title" $>$ Purification of industrial and waste water using matrix-isolated nanocomposite flocculant-coagulants $</$ span $>$ by $<$ a xmlns:cc $="$ http://creativecommons.org/ns\#" href="Nanotehnologii v stroitel'stve $=$ Nanotechnologies in Construction. 2017, Vol. 9, no. 3, pp. 44-61. DOI: dx.doi.org/10.15828/2075-8545-2017-9-3-44-61" property="cc:attributionName" rel="cc:attributionURL">Kudryavtsev P.G., Kudryavtsev N.P., Figovsky O.L. $</ a>$ is licensed under a $<$ a rel="license" href="http://creativecommons.org/licenses/by/4.0/">Creative Commons Attribution 4.0 International License $</ \mathrm{a}>$. $<\mathrm{br} />$ Based on a work at $<$ a xmlns:dct="http://purl.org/dc/terms/" href=" http://nanobuild.ru/ en_EN/nanobuild-3-2017/" rel="dct:source" > http://nanobuild.ru/en_EN/nanobuild-3-2017/</a $>$. $<$ br $/>$ Permissions beyond the scope of this license may be available at $<$ a xmlns:cc="http://creativecommons.org/ns\#" href="figovsky@gmail.com" rel=

"cc:morePermissions">figovsky@gmail.com $</ \mathrm{a}>$.

\section{References:}

1. Zapolsky A.K., Baran A.A. Koaguljanty i flokuljanty v processah ochistki vody: Svojstva. Poluchenie. Primenenie [Coagulants and flocculants in water purification processes: Properties. Receiving. Application.] Leningrad. Chemistry, 1987. (In Russian).

2. Kruchinina N.E., Tournament V.N., Lisyuk B.S., Kim V. Method of obtaining aluminosilicate coagulant. Patent of the Russian Federation No. 2225838, IPC 7, $\mathrm{C} 01 \mathrm{~F} 7$ / 56, C01F7 / 74, C02F1 / 52.

3. Kruchinina N.E. AKFK kak al'ternativa tradicionnym koaguljantam v processah vodoochistki i vodopodgotovki [ASFC as an alternative to traditional coagulants in the processes of water purification and water treatment]. Ecology of production. 2006. No. 2. P. 46-50. (In Russian).

4. Kudryavtsev P.G., Nedugov A.N., et al. Method for the preparation of an aluminasilica flocculant-coagulant, and a method for purifying water with its help, Patent of the Russian Federation No. 2388693 IPC, C01B33 / 26, C01F7 / 74, C02F1 / $52 .-2008$. 
6. Nedugov A.N., Kudryavtsev P.G., Kudryavtsev N.P., et al. Method for the preparation of a composite silica-alumina flocculant-coagulant, Patent of the Russian Federation No. 2447021 IPC, C01B33 / 26, C02F1 / 52, C01F7 / 74. - 2010.

7. Nedugov A.N., Kudryavtsev P.G., Kudryavtsev N.P., et al. Method for the preparation of an iron-silicon flocculant-coagulant and a method for treating water, Patent of the Russian Federation No. 2438993 IPC, C02F1 / 52, C01G49 / 14, C01B33 / 32, B01D21 / 01. - 2010.

8. Kudryavtsev P.G., Kudryavtsev N.P. Novye vysokotehnologichnye kompozicionnye flokuljanty-koaguljanty kak al'ternativa izvestnym reagentam vodoochistki [New high-tech composite flocculants-coagulants as an alternative to known reagents for water purification]. International Scientific Journal «Alternative Energy and Ecology». ISJAEE, 2016. No. 11-12. P. 94-104.

9. Methodical instructions. 4.1. Control methods. Chemical factors determining the mass concentration of petroleum products in water, MUK 4.1.1013-01, MINZDRAV RUSSIA, Moscow, 2001.

10. Pavlova S., Dobrevsky I. Modified Sirofloc process for natural water treatment, Desalination, vol. 173 2005, p. 55-59, doi: 10.1016/j.desal.2004.07.043.

11. Pavlova S. Sirofloc process for natural water treatment, Second Int. Symp. Ecology 93, 1993, pp. 241-247.

12. El-Bestawy E., El-Sokkary I., Hussein H., Abu Keela A.F. Pollution control in pulp and paper industrial effluents using integrated chemical-biological treatment sequences, J. Ind. Microbiol. Biotechnol. 35, 2008, p. 1517-1529.

13. Chen S., Cheng H., Yang S. In-line coagulation/ultrafiltration for silica removal from brackish water as membrane pretreatment, Sep. Purif. Technol, 70, 2009, p. 112-117.

14. Ma W., Zhao Y., Wang $L$. The pretreatment with enhanced coagulation and a UF membrane for seawater desalination with reverse osmosis, Desalination, vol. 203, 2007, p. 256-259.

15. Al-Rehaili A.M. Comparative chemical clarification for silica removal from RO groundwater feed, Desalination, vol. 159, 2003, p. 21-31.

16. Aguilar M.I., Saez J, Llorens M., Soler A., Ortuño J.F. Physico-chemical treatments of wastewaters, Coagulation-flocculation, first ed., University of Murcia, Murcia, 2002.

17. Ye C., Wang D., Shi B., Yu J., Qu J., Edwards M., Tang H.M. Alkalinity effect of coagulation with polyaluminum chlorides: role of electrostatic patch, Colloids Surf., vol. A 294, 2007, p. 163-173. 
18. Miranda R., Negro C., Blanco A. Internal treatment of process waters in paper production by dissolved air Flotation with newly developed chemicals. 2. Field trials, Ind. Eng. Chem. Res. Vol. 48, 2009, p. 3672-3677.

19. Pernitsky D.J., Edzwald J.K. Selection of alum and polyaluminum coagulants: principles and applications, J. Water Supply Res. Technol.-AQUA, vol. 55, 2006, p. 88-98.

20. Lee K.E., Morad N, Teng T.T., Poh B.T. Development, characterization and application of hybrid materials in coagulation/flocculation of wastewater: a review, Chem. Eng. J., vol. 203, 2012, p. 370-386.

21. Wu X., Ge X., Wang D., Tang H. Distinct coagulation mechanism and model between alum and high Al13-PACl, Colloids Surf. A 305 (2007) 89-96.

22. Ahmad A.L., Wong S.S., Teng T.T., Zuhairi A. Improvement of alum and PACl coagulation by polyacrylamides (PAMs) for the treatment of pulp and paper mill wastewater, Chem. Eng. J., vol. 137, 2008, p. 510-517.

23. Latour I., Miranda R., Blanco A. Silica removal from newsprint mill effluents with aluminum salts, Chemical Engineering Journal, vol. 230, 2013, p. 522-531, http://dx.doi.org/10.1016/j.cej.2013.06.039

\section{DeAr COlleagues!}

THE REFERENCE TO THIS PAPER HAS THE FOLLOWING CITATION FORMAT:

Kudryavtsev P.G., Kudryavtsev N.P., Figovsky O.L. Purification of industrial and waste water using matrix-isolated nanocomposite flocculant-coagulants. Nanotehnologii v stroitel'stve $=$ Nanotechnologies in Construction. 2017, Vol. 9, no. 3, pp. 44-61. DOI: dx.doi.org/10.15828/2075-8545-2017-9-3-44-61. (In Russian).

Contact information
Figovsky Oleg Lvovich

figovsky@gmail.com 
УДК 69.001.5+ 696.1

Автор: КУДРЯВЦЕВ Павел Геннадьевич, профессор, D.Sc., ведущий научный сотрудник

Polymate - Israel Research Center (Израиль), действительный член (академик) МАНЭБ и РАЕН, автор 207 научных работ, в том числе 4 монографий, имеет 34 изобретения, награжден медалью им. М.В. Ломоносова, кавалер ордена «Звезда Ученого», удостоен почетного звания «Заслуженный деятель науки», награжден медалью П.А. Столыпина и почетным бриллиантовым знаком Торговопромышленной палаты РФ; РОВох 73, Migdal HaEmek, Polymate Ltd. - Israel Research Center, 10550, Израиль, е-mail: pgkudr89@gmail.com;

Автор: КУДРЯВЦЕВ Николай Павлович, инженер-исследователь Polymate - Israel Research Center (Израиль), автор 9 научных работ, имеет 3 патента; закончил Пермский национальный исследовательский политехнический университет по специальности Химическая технология топлива и природных энергоносителей, прошел стажировку в Университете Фридриха-Александра в Эрлангене и Нюрнберге (Германия) по теме Физико-химические основы процессов разделения; POBox 73, Migdal HaEmek, Polymate Ltd. - Israel Research Center, 2320001, Израиль, e-mail: nikkudr@yahoo.com;

Автор: ФИГОВСКИЙ Олег Львович, профессор, действительный член Европейской академии наук, иностранный член РИА и РАACH, главный редактор журналов SITA, OCJ и RPCS, директор по науке и развитию Polymate - Israel Research Center (Израиль) и Nanotech Industries Inc. (USA), зав. кафедрой ЮНЕСКО «Зелёная химия», президент Израильской ассоциации изобретателей, лауреат Golden Angel Prize, кавалер орденов «Инженерная слава» (Россия) и «Leading Intellectuals of the World» (USA); POBox 73, Migdal HaEmek, Polymate Ltd. - Israel Research Center, 10550, Израиль, e-mail: figovsky@gmail.com

\section{ОЧИСТКА ПРОМЫШЛЕННЫХ И СТОЧНЫХ ВОД С ИСПОЛЬЗОВАНИЕМ МАТРИЧНО-ИЗОЛИРОВАННЫХ НАНОКОМПОЗИЦИОННЫХ ФЛОКУЛЯНТОВ-КОАГУЛЯНТОВ}

\section{АННОТАЦИЯ К СТАТЬЕ (АВТОРСКОЕ РЕЗЮМЕ, РЕФЕРАТ):}

В данной работе представлены результаты исследований по очистке производственных нефтесодержащих сточных вод с применением новых нанокомпозиционных флокулянтов-коагулянтов АКФК и ФКФК. С их помощью испытаны методы обработки сточных вод промышленных предприятий, а также ливневых вод, содержащих нефтепродукты. Рассмотрены конкретные примеры водоочистки с использованием новых алюмокремниевых и железокремниевых флокулянтов-коагулянтов. Авторами разработана и запатентована технология получения флокулянтов-коагулянтов данного типа в твердом виде. Для получения таких композиционных материалов ис- 
пользован метод матричной изоляции действующих активных компонентов. Дана оценка эффективности действия коагулянтов-флокулянтов АКФК и ЖКФК на реальных промышленных сточных водах. Проведено сравнение новых композиционных материалов с известными аналогами.

Ключевые слова: реагентная очистка воды, природные воды, сточные воды, флокулянты-коагулянты, матричная изоляция, нанокомпозиты, АКФК, ЗККФК

МАшИНОЧИТАЕМАЯ ИНФОРМАЦИЯ о CC-лИЦЕНЗИИ в МЕТАДАННЫХ СТАТЬИ (HTML-КОД):

$<$ a rel="license" href="http://creativecommons.org/licenses/by/4.0/"><img alt="Лицензия Creative Commons" style="borderwidth:0" src="https://i.creativecommons.org/l/by/4.0/88x31.png" / $></ \mathrm{a}><$ br $/>$ Произведение «<span xmlns:dct="http:// purl.org/dc/terms/" href="http://purl.org/dc/dcmitype/Text" property="dct:title" rel="dct:type">Очистка промышленных и сточных вод с использованием матрично-изолированных нанокомпозиционных флокулянтов-коагулянтов $</ \operatorname{span}>$ " созданное автором по имени $<\mathrm{a}$ xmlns:cc="http://creativecommons.org/ns\#" href="Нанотехнологии в строительстве. 2017. - Том 9, № 3. - C. 44-61. - DOI: dx.doi.org/10.15828/2075-8545-2017-9-3-44-61." property="cc:attributionName" rel ="cc:attributionURL"> Кудрявцев П. Г., Кудрявцев Н.П., Фиговский О.Л. </a>, публикуется на условиях $<$ a rel="license" href="http://creativecommons.org/licenses/by/4.0/">лицензии Creative Commons «Attribution» («Атрибуция») 4.0 Всемирная $</ \mathrm{a}>$. $<$ br />Основано на произведении с $<$ a xmlns:dct="http://purl.org/dc/terms/" href="http://nanobuild.ru/ru_RU/ nanobuild-3-2017/" rel="dct:source">http://nanobuild.ru/ru_RU/nanobuild-3-2017/</a >.<br />Разрешения, выходящие за рамки данной лицензии, могут быть доступны на странице <a xmlns:cc="http://creativecommons.org/ns\#" href="figovsky@ gmail.com" rel="cc:morePermissions" $>$ figovsky@gmail.com $</ a>$.

\section{Введение}

Сегодня нефть и нефтепродукты являются одним из основных видов загрязнения сточных вод. Источниками сточных вод, содержащих нефть и продукты ее переработки, являются нефтедобывающие компании, доставка нефтепродуктов, места их хранения, переработки и использования. Еще одним источником сточных вод, содержащих нефтепродукты, являются автомойки. Такие сточные воды являются одними из наиболее экологически опасных объектов из-за содержащихся в них токсичных нефтепродуктов. ПДК нефтепродуктов для сброса в открытые водоемы составляет 0,05 мг/л, а на сооружениях биологической очистки их содержание колеблется, в зависимости от нагрузки, в пределах от 2 до 20 мг/л. 
В этой связи для очистки сточных вод от нефтепродуктов, находящихся в грубодисперсном и тонкодисперсном состоянии, как правило, применяют технологические схемы, которые включают не только механическую очистку, но и коагуляцию с применением коагулянтов. Коагулянты, в свою очередь, используются как отдельно, так и совместно с флокулянтами. Одним из способов повышения эффективности коагуляционной очистки нефтесодержащих сточных вод, особенно на действующих очистных сооружениях, является применение новых более эффективных реагентов и композиций на их основе. $К$ таким реагентам относятся смешанные коагулянты АКФК и ФКФК, которые, в отличие от сернокислых солей алюминия и железа, содержат соединения кремния и проявляют свойства коагулянта и флокулянта [1-8].

В некоторых работах отмечалось, что удаление кремнезема проводится во время процесса смягчения воды, при этом необходимо обеспечивать достаточную жесткость воды, особенно магниевую жесткость. С другой стороны, было проведено несколько исследований с использованием традиционных коагулянтов, таких как квасцы или хлорид железа, для очистки кремнийсодержащих сточных вод, например целлюлозно-бумажного производства [12]. В этом случае коагуляция с квасцами оказалась более эффективной для удаления кремнезема, чем хлорид железа. Коагуляция и ультрафильтрация также успешно использовались для обработки солоноватой воды, чтобы избежать проблем с диоксидом кремния $[13,14]$. Были также изучены квасцы, хлорид железа и алюминат натрия для улучшения скорости удаления диоксида кремния в процессе очистки солоноватой водой [15]. Полиалюминий хлориды эффективны при низких температурах в более широком диапазоне $\mathrm{pH}$, они образуют компактные легко осаждаемые хлопья. При их использовании очень низка вероятность передозировки и они менее чувствительны к разбросу свойств воды $[16,17]$. Поскольку хлориды могут вызвать проблемы с коррозией, иногда они частично замещаются другими соединениями, такими как сульфаты или нитраты, обеспечивая новый ассортимент продуктов. Основными различиями между этими продуктами являются их основность, прочность и содержание в воде других ионов, таких как кремнезем, кальций или даже органические соединения [18-20]. Хотя механизм удаления кремнезема с использованием полиалюминиевых коагулянтов недостаточно изучен $[17,21]$, существует единое мнение в том, что они действуют по двум 
механизмам. Механизмы первичной коагуляции [18, 22]: (1) нейтрализация зарядов отрицательных частиц за счет адсорбции положительно заряженных растворенных ионов алюминия; (2) адсорбция частиц на поверхности осажденного $\mathrm{Al}(\mathrm{OH})_{3}$.

Поэтому представляет практический интерес сравнение коагулирующих свойств разработанных нами смешанных коагулянтов и индивидуальных продуктов при очистке нефтесодержащих сточных вод разных видов, что и явилось целью настоящей работы.

Впервые жидкий алюмокремниевый флокулянт-коагулянт (АКФК) был создан с использованием метода обработки нефелина серной кислотой [2]. Недостатками данного продукта являются его небольшой срок хранения (в течение нескольких суток раствор АКФК превращается в гель и теряет свойства флокулянта-коагулянта), сложность процесса изготовления, использование стабилизирующих полимерных добавок и значительные энергозатраты. Именно поэтому, а также в силу экономической нецелесообразности транспортировки раствора, применение алюмокремниевого флокулянта-коагулянта должно было быть сосредоточено в местах его производства. Этот фактор сдерживал практическое использование АКФК в промышленной практике очистки сточных вод, поэтому актуальным является поиск новых реагентов подобного типа и условий их стабилизации.

Алюмокремниевый флокулянт-коагулянт (АКФК) является одной из немногих бинарных композиций, в состав которой входят только неорганические компоненты: коагулянт (сульфат алюминия) и анионный флокулянт (активная кремниевая кислота). Действие АКФК основано на том, что в результате взаимодействия первичных компонентов АКФК - коагулянта и флокулянта - образуются комплексные соединения, обладающие более высокой флоккулирующей способностью. Они представляют собой цеолитоподобные наноразмерные структуры с развитой сорбционной поверхностью, которая и обеспечивает механизм очистки воды. В результате наблюдается синергетический эффект, связанный с возрастанием эффективности, обусловленной интеграцией отдельных процессов в единую систему.

Авторами был разработан способ получения алюмокремниевого флокулянта-коагулянта в виде кристаллического продукта, который обладает более высокой стабильностью. Срок хранения продукта составляет более 6 месяцев. Кроме того, он эффективен и прост в использова- 
нии, прост в изготовлении и экономичен при транспортировке, может иметь более высокое содержание активной составляющей: содержание алюминия в пересчете на оксид алюминия $-6,8 \div 12,7 \%$, кремния в пересчете на оксид кремния $-10,2 \div 18,6 \%$ [4-7].

В этот метод синтеза были заложены принципы, лежащие в основе известного метода матричной изоляции, получившей развитие в конце прошлого века. Использование подобных технологических приемов позволило заморозить и изолировать в матрице твердой фазы компоненты флокулянта-коагулянта - кислые соли сульфата алюминия и активную кремниевую кислоту, находящуюся в нанодисперсном состоянии с размером частиц от $2 \div 10$ нм. Быстрый перевод активных компонентов в твердое состояние позволяет резко снизить скорости диффузионных процессов и при этом сохранить активность материала.

Среди известных реагентов для водоподготовки существует отдельный класс железосодержащих коагулянтов. Из солей железа наиболее употребительны сульфаты железа (II) и хлорид железа (III) [10]. Соли железа обладают лучшими коагулирующими свойствами в ин-

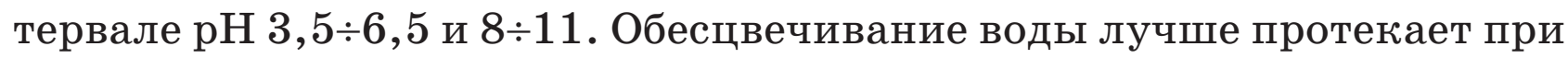
$\mathrm{pH} 3,5 \div 5,0$. Соли железа предпочтительно применять при очистке мутных жестких вод с высоким значением $\mathrm{pH}$, а также при очистке стоков [1]. Они позволяют устранять запахи и привкусы, обусловленные присутствием сероводорода, удалять соединения мышьяка, марганца, меди, а также способствуют окислению органических соединений. По сравнению с солями алюминия соли железа могут применяться при очистке вод с более разнообразным солевым составом и различными значениями $\mathrm{pH}$, они оказывают лучшее действие при низких температурах, характеризуются большой прочностью и гидродинамическими размерами хлопьев. Применение методов синтеза, использованных для получения алюмокремниевых флокулянтов-коагулянтов, в частности, использование подходов матричной изоляции активных компонентов, позволило создать аналогичные продукты на основе соединений железа [7].

\section{Методики и объекты исследований}

В работе были использованы известные стандартные методы исследований и анализа, которые изложены в предыдущем отчете. 
Количественное определение нефтепродуктов осуществлялось методом ИК-спектроскопии с применением прибора для определения нефтепродуктов марки КН-2. Методика основана на выделении эмульгированных и растворенных нефтяных компонентов из воды экстракцией четыреххлористым углеродом, хроматографическом отделении нефтепродуктов от сопутствующих органических соединений других классов на колонке, заполненной оксидом алюминия, с последующим количественным определением их массовой концентрации по интенсивности поглощения $\mathrm{C}-\mathrm{H}$ связей в инфракрасной области спектра на концентратомере КН-2. Диапазон определяемых концентраций нефтепродуктов (НП) от 0,02 до 2,00 мг/дм ${ }^{3}$ [9]. Мешающее влияние других веществ, присутствующих в пробе воды, устраняется в процессе подготовки проб.

Эффективность коагулянтов определяли методом пробной коагуляции на лабораторной установке «Капля» с механическим перемешиванием по схеме, смешением, хлопьеобразованием и отстаиванием.

Смешение осуществляли в течение одной мин при среднем градиенте скорости $\mathrm{G}=500 \mathrm{c}^{-1}$, хлопьеобразование - в течение 5 мин при $\mathrm{G}=$ $50 \mathrm{c}^{-1}$. Отстаивание осуществляли в течение 5 мин для выделения загрязнений с гидравлической крупностью более 0,03 мм/с.

Эксперименты проводили на реальной нефтесодержащей сточной воде, характеристики которой представлены в табл. 1.

Таблица 1

Характеристики нефтесодержащих сточных вод, использованных в качестве экспериментальных объектов

\begin{tabular}{|l|c|c|c|}
\hline \multicolumn{1}{|c|}{ Показатель } & $\begin{array}{c}\text { Общий сток нефте- } \\
\text { перерабатывающе- } \\
\text { го завода (НП3) }\end{array}$ & $\begin{array}{c}\text { Сточная вода } \\
\text { автомойки }\end{array}$ & $\begin{array}{c}\text { Ливневой сток } \\
\text { нефтебазы }\end{array}$ \\
\hline $\mathrm{pH}$ & 7,48 & $6,92 \div 7,1$ & $7,48 \div 7,6$ \\
\hline Нефтепродукты & 5,5 & $50,5 \div 139,54$ & $46,7 \div 83,0$ \\
\hline Мутность, мг/л & 47 & $74,8 \div 106,9$ & $84,0 \div 154,0$ \\
\hline Цветность, град.* & 301 & 83 & 47 \\
\hline
\end{tabular}

* цветность измерялась в градусах хром-кобальтовой шкалы 
Сточная вода нефтеперерабатывающего завода (Ярославль) представляла собой мутную желтовато-зеленоватую жидкость с запахом нефтепродуктов. Ливневой сток нефтебазы и сточная вода автомойки представляли собой соответственно светло-серую и темно-серую не осветляемую при длительном отстаивании жидкость с сильным запахом нефтепродуктов.

Проведены исследования свойств флокулянтов-коагулянтов АКФК и ФКФК. Для сравнения взяты стандартные продукты - сульфат алюминия (CA) и сульфат железа (II) (СЖ, железный купорос). Характеристики исследованных коагулянтов представлены в работе [8].

\section{Эффективность применения композиционных коагулянтов АКФК и ФКФК для очистки нефтесодержащих сточных вод}

\section{1. Сравнение коагулирующей способности коагулянтов при очистке сточных вод НПЗ}

Результаты по эффективности снижения мутности, цветности и содержания нефтепродуктов в сточной воде НПЗ алюминий содержащими коагулянтами в зависимости от их дозы представлены на рис. 1А. Как следует из полученных данных, АКФК и СА обладают близкой коагулирующей активностью и обеспечивают практически равное снижение мутности и содержания нефтепродуктов при самостоятельном применении, при дозах 10-20 мг/л (по оксиду алюминия). Однако АКФК обеспечивает большее снижение цветности, чем СА во всем интервале испытанных доз реагентов от 5 до 46 мг/л (рис. 1). При использовании железосодержащих коагулянтов мутность и цветность сточной воды НПЗ снижается в равной степени флокулянтом-коагулянтом ФКФК и железным купоросом, а содержание нефтепродуктов в очищенной воде значительно ниже при применении ФКФК, чем железного купороса (рис. 1Б).

При дозе коагулянтов 5 мг/л остаточное содержание нефтепродуктов в очищенной воде также ниже при коагуляции ФКФК, чем при коагуляции железным купоросом. Проведенные эксперименты в работах $[10,11]$ показали, что подкисление воды облегчает удаление коллоидных веществ. Доля гуминовых кислот (которые составляют большинство коллоидных соединений в природных водах) увеличивается 

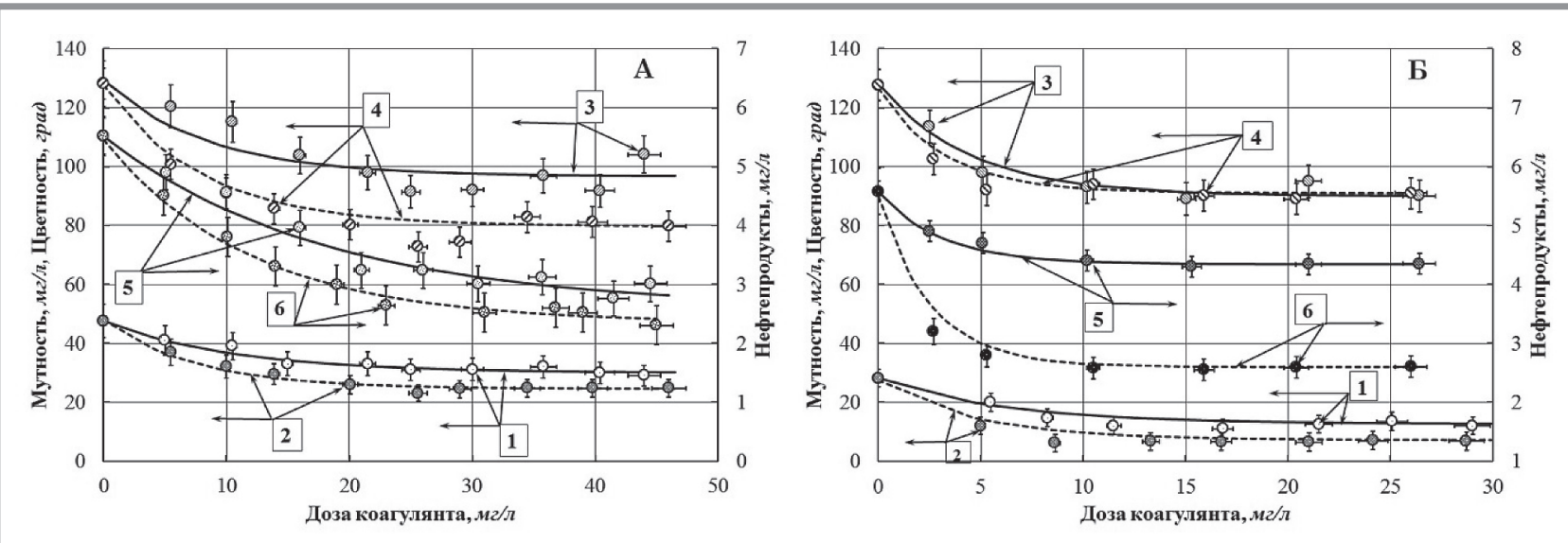

Рuc. 1. Зависимость мутности $(1,2)$, цветности $(3,4)$ и содержания нефтепродуктов

$(5,6)$ отстоянной сточной воды НПЗ от дозы реагентов: сульфат алюминия (А) или сульфат железа (II) (Б) $(1,3,5)$ и флокулянт-коагулянта $(2,4,6)$. А - АКФК; Б - ЗॅКФК

с уменьшением pH. Однако подкисление воды приводит к определенным трудностям при практической реализации процесса, авторы работ $[10,11]$ проводили эксперименты при рН воды 7,8-7,9. Однако оптимальная величина рН при применении ФКФК составляет $8,3 \div 8,7$, как показано на рис. 2.

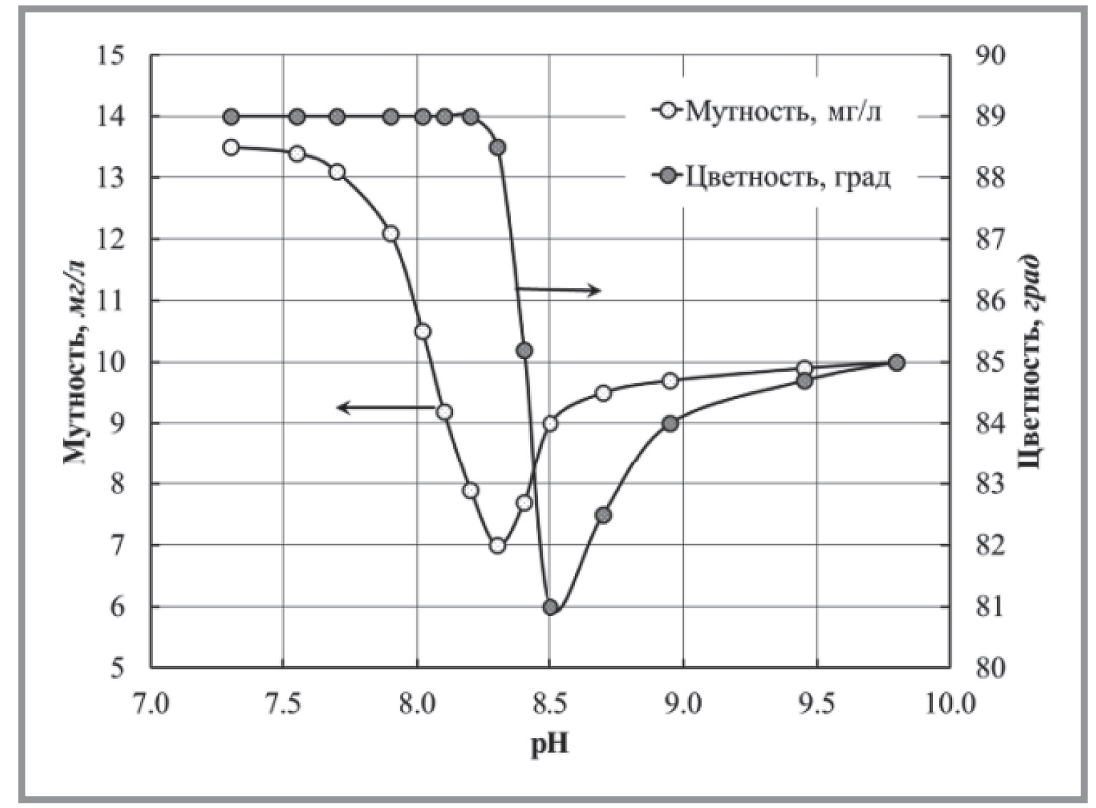

Puc. 2. Зависимость мутности и цветности сточной воды НПЗ от рН при дозе ФКФК 30 мг/л, при продолжительности отстаивания в течение 10 мин. 
Сравнение коагулирующей способности алюмо- и железосодержащих коагулянтов показало, что для обеспечения одинакового эффекта очистки сточных вод НПЗ железосодержащие коагулянты требуются в дозах, в 2 раза меньших (5 мг/л), чем дозы алюмосодержащих коагулянтов $(10 \mathrm{мг} / л)$.

\section{2. Сравнение коагулирующей способности коагулянтов при очистке сточной воды автомойки}

Экспериментальные результаты, полученные по эффективности применения композиционных флокулянтов-коагулянтов АКФК, ФКФК и базовых коагулянтов - сульфатов алюминия и железа (II) для очистки сточной воды автомойки, представлены на рис. 3 А. Как следует из рис. 3 , коагулянт-флокулянт АКФК в большей степени, чем CA, снижает мутность сточной воды при одинаковом остаточном содержании нефтепродуктов. Коагулянт ФКФК в большей степени, чем СЗ (рис. 3Б), снижает мутность и содержание нефтепродуктов.

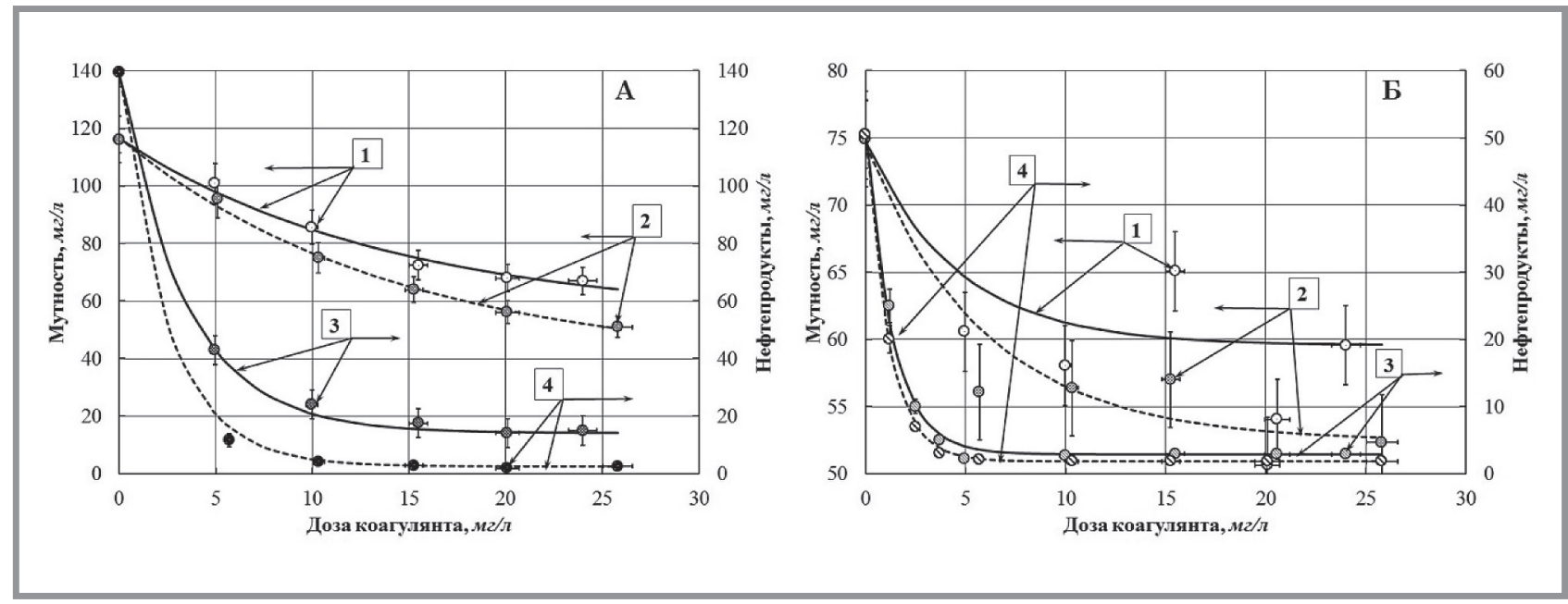

Рuc. 3. Зависимость мутности $(1,2)$ и содержания нефтепродуктов $(3,4)$ отстоянной сточной воды автомойки от дозы реагентов: сульфат алюминия (А) или сульфат железа (II) (Б) $(1,3)$ и флокулянт-коагулянта $(2,4)$.

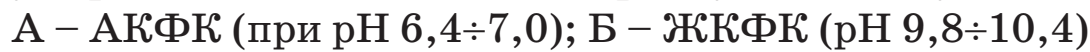




\section{3. Сравнение коагулирующей способности коагулянтов при очистке ливневых сточных вод нефтебазы}

Эксперименты по очистке ливневых сточных вод нефтебазы, так же, как и при очистке сточных вод НПЗ и автомойки, показали высокую эффективность применения флокулянтов-коагулянтов. При этом удается обеспечить максимальное снижение содержания нефтепродук-

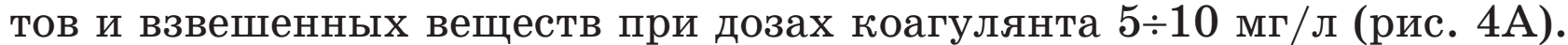
По эффективности коагулянт АКФК несколько лучше, чем СА (рис. 4A). В то же время коагулянт ФКФК в дозе 5 мг/л обеспечивает значительное меньшее содержание нефтепродуктов в очищенной воде, чем Сふ при одновременном снижении мутности очищенной воды (рис. 4 Б).

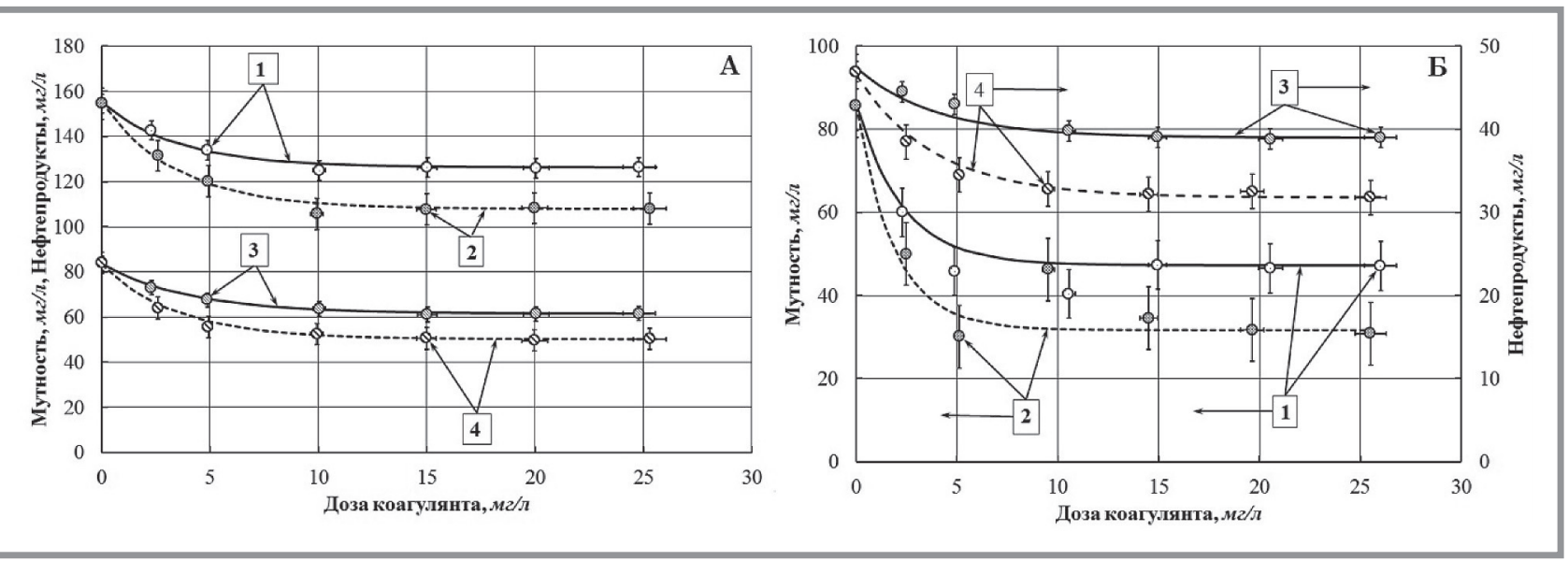

Рuc. 4. Зависимость качества отстоянной мутности $(1,2)$ и содержания нефтепродуктов $(3,4)$ после коагуляции сточной воды нефтебазы от дозы алюмосодержащих коагулянтов: сульфат алюминия (A) или сульфат железа (II) (Б) $(1,3)$ и флокулянт-коагулянта $(2,4)$.

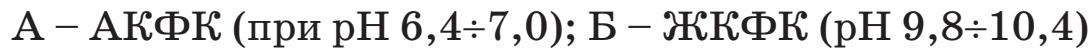

\section{4. Обсуждение результатов}

Представленные на рис. 1-4 результаты хорошо описываются экспоненциальной зависимостью:

$$
P=P_{0}-A+A \cdot e^{-\frac{c \cdot \ln 2}{C_{0,5}},}
$$


где $P$ - измеряемый параметр для сточной воды (мутность, содержание нефтепродуктов, цветность); $A$ - максимальная величина снижения измеряемого параметра под действием флокулянта-коагулянта; $c$ - доза флокулянта-коагулянта в сточной воде (мг/л); $C_{0,5}-$ доза флокулянта-коагулянта в сточной воде, при которой достигается $50 \%$ от величины снижения измеряемого параметра. То есть:

$$
A=2 \cdot\left(P_{0}-P\left(C_{0,5}\right)\right) \text {, }
$$

где $P\left(C_{0,5}\right)$ - величина измеряемого параметра при дозе флокулянтакоагулянта в сточной воде, равной $C_{0,5}$.

Результаты обработки экспериментальных данных с использованием указанного выше уравнения представлены в табл. 2 . Из этих данных

Таблица 2

Параметры воздействия стандартных коагулянтов и разработанных композиционных флокулянтов-коагулянтов на сточные воды различных предприятий, содержащие нефтепродукты

\begin{tabular}{|c|c|c|c|c|c|c|c|}
\hline & \multirow{2}{*}{$\begin{array}{c}\text { Тип } \\
\text { коагу- } \\
\text { лянта }\end{array}$} & \multicolumn{2}{|c|}{ Мутность } & \multicolumn{2}{|c|}{ Нефтепродукты } & \multicolumn{2}{|c|}{ Цветность } \\
\hline & & $C_{0,5}$ & $A, \%$ & $C_{0,5}$ & $A, \%$ & $C_{0,5}$ & $A, \%$ \\
\hline \multirow{2}{*}{$\begin{array}{l}\text { Сточная вода НПЗ } \\
\text { (Ярославль) }\end{array}$} & $\mathrm{CA}$ & 7,37 & 37,0 & 12,40 & 48,6 & 5,84 & 24,5 \\
\hline & АКФК & 5,22 & 48,3 & 8,26 & 58,3 & 5,56 & 37,8 \\
\hline \multirow{2}{*}{$\begin{array}{l}\text { Сточная вода } \\
\text { автомойки }\end{array}$} & $\mathrm{CA}$ & 9,76 & 53,4 & 2,36 & 89,9 & & \\
\hline & АКФК & 9,79 & 67,5 & 1,72 & 98,2 & & \\
\hline \multirow{2}{*}{$\begin{array}{l}\text { Сточная вода } \\
\text { нефтебазы }\end{array}$} & $\mathrm{CA}$ & 2,41 & 18,2 & 2,79 & 26,6 & & \\
\hline & АКФК & 2,36 & 30,2 & 2,38 & 40,1 & & \\
\hline \multirow{2}{*}{$\begin{array}{l}\text { Сточная вода НПЗ } \\
\text { (Ярославль) }\end{array}$} & СЖ & 4,29 & 54,9 & 2,13 & 22,1 & 3,09 & 29,5 \\
\hline & ЖКФК & 3,32 & 74,4 & 1,75 & 53,4 & 2,23 & 28,7 \\
\hline \multirow{2}{*}{$\begin{array}{l}\text { Сточная вода } \\
\text { автомойки }\end{array}$} & СЖ & 3,17 & 20,5 & 0,93 & 94,3 & & \\
\hline & ЖКФК & 4,11 & 30,0 & 0,81 & 96,3 & & \\
\hline \multirow{2}{*}{$\begin{array}{l}\text { Сточная вода } \\
\text { нефтебазы }\end{array}$} & СЖ & 1,58 & 44,8 & 2,74 & 16,8 & & \\
\hline & ЗККФК & 1,30 & 63,0 & 2,68 & 32,2 & & \\
\hline
\end{tabular}


можно видеть объективную характеристику оценки воздействия каждого из использованных реагентов. Также можно заключить, что различное действие реагентов на различные сточные воды, по-видимому, связано с различиями в химическом составе примесей нефтепродуктов, имеющихся в различной сточной воде.

\section{Заключение}

Экспериментально показано, что композиционные флокулянтыкоагулянты АКФК и ФКФК являются самыми эффективными реагентами для очистки нефтесодержащих сточных вод из тех реагентов, которые прошли испытания - СА, ЗКС, АКФК, ФКФК. Композиционный флокулянт-коагулянт АКФК является более эффективным для снижения цветности сточных вод, по сравнению с ЗККФК, что обусловлено отсутствием окраски соединений алюминия по сравнению с соединениями железа. Композиционный флокулянт-коагулянт ЗККФК является наиболее эффективным для снижения содержания нефтепродуктов в сточных водах.

\section{Библиографический список:}

1. Запольский А.К., Баран А.А. Коагулянты и флокулянты в процессах очистки воды: Свойства. Получение. Применение. - Л.: Химия, 1987.

2. Кручинина Н.Е., Турниер В.Н., Лисюк Б.С., Ким В. Способ получения алюмосиликатного коагулянта // Патент РФ № 2225838 МПК 7, С01F7/56, $\mathrm{C} 01 \mathrm{~F} 7 / 74, \mathrm{C} 02 \mathrm{~F} 1 / 52$.

3. Кручинина H.E. АКФК как альтернатива традиционным коагулянтам в процессах водоочистки и водоподготовки // Экология производства. - 2006. № 2. - C. $46-50$.

4. Кудрявиев П.Г., Недугов А.Н. и др. Способ получения алюмокремниевого флокулянта-коагулянта и способ очистки с его помощью воды // Патент РФ № 2388693 МПК, С01B33/26, C01F7/74, C02F1/52. - 2008.

6. Недугов А.Н., Кудрявиев П.Г., Кудрявиев Н.П. и др. Способ получения композиционного алюмокремниевого флокулянта-коагулянта // Патент РФ № 2447021 МПК, С01B33/26, C02F1/52, C01F7/74. - 2010. 
7. Недугов А.Н., Кудрявиев П.Г., Кудрявиев Н.П. и др. Способ получения железокремниевого флокулянта-коагулянта и способ обработки воды // Патент РФ № 2438993 МПК, C02F1/52, C01G49/14, C01B33/32, B01D21/01. - 2010.

8. Кудрявиев П.Г., Кудрявцев Н.П. Новые высокотехнологичные композиционные флокулянты-коагулянты как альтернатива известным реагентам водоочистки / Международный научный журнал «Альтернативная энергетика и экология» . - ISJAEE, 2016. - № 11-12. - С. 94-104.

9. Методические указания. 4.1. Методы контроля. Химические факторы определения массовой концентрации нефтепродуктов в воде // МУК 4.1.101301. - Минздрав России. - Москва, 2001.

10. Pavlova S., Dobrevsky I. Modified Sirofloc process for natural water treatment, Desalination, vol. 173 2005, p. 55-59, doi: 10.1016/j.desal.2004.07.043.

11. Pavlova S. Sirofloc process for natural water treatment, Second Int. Symp. Ecology 93, 1993, pp. 241-247.

12. El-Bestawy E., El-Sokkary I., Hussein H., Abu Keela A.F. Pollution control in pulp and paper industrial effluents using integrated chemical-biological treatment sequences, J. Ind. Microbiol. Biotechnol. 35, 2008, p. 1517-1529.

13. Chen S., Cheng H., Yang S. In-line coagulation/ultrafiltration for silica removal from brackish water as membrane pretreatment, Sep. Purif. Technol, 70, 2009, p. 112-117.

14. Ma W., Zhao Y., Wang L. The pretreatment with enhanced coagulation and a UF membrane for seawater desalination with reverse osmosis, Desalination, vol. 203, 2007, p. 256-259.

15. Al-Rehaili A.M. Comparative chemical clarification for silica removal from RO groundwater feed, Desalination, vol. 159, 2003, p. 21-31.

16. Aguilar M.I., Saez J, Llorens M., Soler A., Ortuño J.F. Physico-chemical treatments of wastewaters, Coagulation-flocculation, first ed., University of Murcia, Murcia, 2002.

17. Ye C., Wang D., Shi B., Yu J., Qu J., Edwards M., Tang H.M. Alkalinity effect of coagulation with polyaluminum chlorides: role of electrostatic patch, Colloids Surf., vol. A 294, 2007, p. 163-173.

18. Miranda R., Negro C., Blanco A. Internal treatment of process waters in paper production by dissolved air Flotation with newly developed chemicals. 2. Field trials, Ind. Eng. Chem. Res. Vol. 48, 2009, p. 3672-3677.

19. Pernitsky D.J., Edzwald J.K. Selection of alum and polyaluminum coagulants: principles and applications, J. Water Supply Res. Technol.-AQUA, vol. 55, 2006, p. 88-98. 
20. Lee K.E., Morad N, Teng T.T., Poh B.T. Development, characterization and application of hybrid materials in coagulation/flocculation of wastewater: a review, Chem. Eng. J., vol. 203, 2012, p. 370-386.

21. Wu X., Ge X., Wang D., Tang H. Distinct coagulation mechanism and model between alum and high Al13-PACl, Colloids Surf., vol. A 305, 2007, p. 89-96.

22. Ahmad A.L., Wong S.S., Teng T.T., Zuhairi A. Improvement of alum and PACl coagulation by polyacrylamides (PAMs) for the treatment of pulp and paper mill wastewater, Chem. Eng. J., vol. 137, 2008, p. 510-517.

23. Latour I., Miranda R., Blanco A. Silica removal from newsprint mill effluents with aluminum salts, Chemical Engineering Journal, vol. 230, 2013, p. 522531, http://dx.doi.org/10.1016/j.cej.2013.06.039.

\section{УВАЖАЕМЫЕ КОЛЛЕГИ!}

ПРИ ИСПОЛЬЗОВАНИИ МАТЕРИАЛА ДАННОЙ СТАТЬИ

ПРОСИМ ДЕЛАТЬ БИБЛИОГРАФИЧЕСКУЮ ССЫЛКУ НА НЕЁ:

Кудрявиев П. Г., Кудрявиев Н.П., Фиговский О.Л. Очистка промышленных и сточных вод с использованием матрично-изолированных нанокомпозиционных флокулянтов-коагулянтов // Нанотехнологии в строительстве. - 2017. Tом 9, № 3. - C. 44-61. - DOI: dx.doi.org/10.15828/2075-8545-2017-9-3-44-61.

\section{DeAr Colleagues!}

THE REFERENCE TO THIS PAPER HAS THE FOLLOWING CITATION FORMAT:

Kudryavtsev P.G., Kudryavtsev N.P., Figovsky O.L. Purification of industrial and waste water using matrix-isolated nanocomposite flocculant-coagulants. Nanotehnologii v stroitel'stve $=$ Nanotechnologies in Construction. 2017, Vol. 9, no. 3, pp. 44-61. DOI: dx.doi.org/10.15828/2075-8545-2017-9-3-44-61. (In Russian).

\begin{tabular}{|c|c|}
\hline $\begin{array}{l}\text { Контактная } \\
\text { иффорлация: }\end{array}$ & $\begin{array}{c}\text { Figovsky Oleg Lvovich } \\
\text { figovsky@gmail.com }\end{array}$ \\
\hline
\end{tabular}

